\title{
HIV knowledge and stigma among dietetic students in Indonesia: implications for the nutrition education system
}

\author{
Mutiara Tirta Prabandari Lintang Kusuma ${ }^{1,2^{*}}$ (D), Tandalayo Kidd ${ }^{2}$, Nancy Muturi ${ }^{3}$, Sandra B. Procter ${ }^{2}$,
} Linda Yarrow ${ }^{2}$ and Wei-Wen Hsu ${ }^{4}$

\begin{abstract}
Background: Studies have demonstrated that health care students and practitioners are not immune to stigma towards people living with HIV (PLHIV). This attitude could lead to poor quality of care if it remains uncorrected. However, little is known about dietetic students' acceptance of PLHIV despite their substantial role in treatment. This study aimed to measure the extent of knowledge and stigma towards PLHIV among dietetic students and to determine the associated factors using the attribution theory.

Methods: Students from three dietetics schools in Indonesia $(n=516)$ were recruited to participate in this crosssectional study. Survey questions covered demographic information, interaction with PLHIV, access to information sources, cultural values, and beliefs as predictor variables. The outcome variables were comprehensive knowledge of HIV, HIV and nutrition-specific knowledge, and attitudes. Analyses with linear regression and the stepwise selection were performed to determine factors related to the outcome.

Results: The levels of HIV comprehensive knowledge and HIV-nutrition specific knowledge among dietetic students were low, as indicated by the average score of $19.9 \pm 0.19$ (maximum score $=35)$ and $8.0 \pm 0.11$ (maximum score $=$ 15), respectively. The level of negative attitudes towards PLHIV was high, with $99.6 \%$ of participants reported having a high stigma score. Types of university affiliation (public or private), beliefs and values, exposure to HIV discourse, access to printed media, and years of study were significantly related to HIV comprehensive knowledge $(p<0.05)$. Nutrition-specific knowledge was also correlated with university affiliation, beliefs and values, participation in HIV discussion, and years of study $(p<0.05)$. HIV comprehensive knowledge, university affiliation, discussion participation, and ethnicities were associated with attitudes $(p<0.05)$.

Conclusions: Awareness and acceptance of PLHIV must be further improved throughout dietetic training to ensure patients' quality of care since students represent future dietary care providers. Considering the consistent findings that affiliation to education institution correlates with HIV knowledge and attitude, some examinations concerning the curriculum and teaching conduct might be necessary.
\end{abstract}

Keywords: HIV, AIDS, Attribution theory, Stigma, HIV knowledge, Nutrition education, Dietetic student

\footnotetext{
* Correspondence: mutiara.tirta@gmail.com

'Department of Nutrition and Health, Faculty of Medicine, Public Health, and Nursing, Universitas Gadjah Mada, Yogyakarta, Indonesia

${ }^{2}$ Department of Food, Nutrition, Dietetics, and Health, College of Health and

Human Sciences, Kansas State University, Manhattan, Kansas, USA

Full list of author information is available at the end of the article
}

(c) The Author(s). 2020 Open Access This article is licensed under a Creative Commons Attribution 4.0 International License, which permits use, sharing, adaptation, distribution and reproduction in any medium or format, as long as you give appropriate credit to the original author(s) and the source, provide a link to the Creative Commons licence, and indicate if changes were made. The images or other third party material in this article are included in the article's Creative Commons licence, unless indicated otherwise in a credit line to the material. If material is not included in the article's Creative Commons licence and your intended use is not permitted by statutory regulation or exceeds the permitted use, you will need to obtain permission directly from the copyright holder. To view a copy of this licence, visit http://creativecommons.org/licenses/by/4.0/ The Creative Commons Public Domain Dedication waiver (http://creativecommons.org/publicdomain/zero/1.0/) applies to the data made available in this article, unless otherwise stated in a credit line to the data. 


\section{Background}

Human Immunodeficiency Virus (HIV) remains a significant public health threat worldwide despite the current situation which shows improvement in the number of new infections and mortality rates. In Indonesia, it is estimated that about 630,000 people were living with HIV at the end of 2017. The data show that HIV incidence decreased from 0.26 to 0.19 between 2010 and 2017 , but the mortality rate increased by approximately $69 \%$ [1].

HIV infection adversely affects individual nutrition status. People living with HIV (PLHIV) are more prone to rapid weight loss and malnutrition due to prolonged infection, eating difficulties, and metabolic alterations [25]. Nutrition problems associated with HIV and its treatment occur in most patients and could be indicative of the stage and progression of the infection. Research suggested that proper nutrition care is necessary to strengthen the immune system, delay the disease progression, and improve patients' quality of life [4-7].

The fact that dietary management is considered as one key pillar in HIV treatment requires the ability of dietitians to transfer knowledge and skills to the patients through nutrition education and counseling [8-10]. However, despite the crucial role of dietitians, little is known about their awareness and ability in performing nutrition care for PLHIV as earlier studies were mostly done among other health providers [11-14]. Unlike doctors and nurses who have close contacts with patients, dietitians' interaction is limited to counseling sessions [15]. This low personal contact with PLHIV may affect their self-awareness concerning prejudice and stigma.

Studies have demonstrated a wide range of levels of HIV-related knowledge and attitudes among healthcare students from different study populations. A study among medical and nursing students in Fiji showed adequate HIV knowledge and favorable attitudes towards HIV patients [16]. Similar results were reported among dental students in the United Arab Emirates [17]. However, a survey among pre-clinical students in Israel found that although their knowledge was relatively good, prejudicial attitudes remained prevalent, which was attributed to shame-related stigma and fear of contagions [18]. This finding corresponds with a study among Turkish nursing students in which the participants expressed hesitation to work with HIV patients due to misconceptions [19].

Acceptance of PLHIV in Indonesia is low in the community and also among health providers [11-13]. UNAIDS reported that the percentage of PLHIV who experienced discriminatory attitudes increased from 57.1 to $62.8 \%$ between 2007 and 2012 [1]. Previous studies also demonstrated a widespread stigmatized attitude among doctors, nurses, and midwives [11, 12,
20]. A study on HIV in hospitals and clinics in Aceh, Indonesia, found a high level of negative attitudes among health professionals, including dietitians. The stigma found in this study was classified as a valuedriven stigma, which corresponded to the blame and shame prejudice. With this attitude, HIV is regarded as a 'disease of a bad person' and immoral; hence, how patients contracted the disease would determine acceptance. Consequently, low HIV testing and counseling uptake, delayed treatments, disengagement from health care, and poor adherence to medication among PLHIV in Indonesia have been widely reported [13, 21, 22].

Dietetic students represent the future of dietetic care, and their academic experiences will be reflected in their future practices. The chances are high that they will find themselves working in the field of HIV and AIDS and engage with the key populations. Therefore, dietetic schools are required to provide to the best of their ability the adequate knowledge and skills needed to provide care for patients with HIV as well as learning experiences that encourage acceptance and willingness to help the patients. Nonetheless, conducting courses about HIV and AIDS is not mandatory for any dietetic school in Indonesia.

This study aimed at measuring the level of knowledge (HIV comprehensive and nutrition-specific knowledge) and stigma towards PLHIV among dietetic students in Indonesia. The attribution theory used in this study is concerned with how common sense operates to explain events and the psychological consequences of such an attribution process, which may present a perceived causality instead of actual causality [23]. This theory is widely used in HIV studies to explain stigma [24]. Because this study is among the first to explore HIV knowledge and attitude among dietetic students in Indonesia, we believe the outcome can substantially contribute to improve the nutrition education system.

\section{Methods \\ Study design}

This research was a cross-sectional analytical study involving three dietetic schools in Indonesia and conducted between 2016 and 2017. Two hypotheses were tested: (1) there is an association between access to HIV-related information with knowledge and attitudes; and (2) there is an association between personal values and HIV knowledge and attitudes.

The ethical considerations of this study were fully approved by the Kansas State University Institutional Board Review (IRB) \# 8555 and the Medical and Health Research Ethics Committee (MHREC) Faculty of Medicine Universitas Gadjah Mada - Dr. Sardjito General Hospital, reference number KE/FK/0129/EC/2017. 


\section{Study setting}

This study was conducted in three dietetic schools in Indonesia: two state universities and one private university. All universities are located in Java island, which has the largest population and highest proportion of HIV cases [25]. Two universities are in Jogjakarta province and one is in Central Java province, both are approximately $500 \mathrm{~km}$ away from Jakarta, the capital city of Indonesia. Both provinces experience increased incidence and prevalence of HIV and AIDS over the years, with Central Java province reporting higher prevalence compared to Jogjakarta province [25]. All universities are affiliated with teaching hospitals that are appointed as HIV referral hospitals. To control the spread of HIV, the Government of Indonesia has appointed 278 referral hospitals throughout the country, under the Indonesian Ministry of Health Decree number 782/ MENKES/SK/IV/2011. All HIV-suspected patients are referred to these hospitals to get tested, counseling, and treatment.

\section{Study participants}

The study population consisted of junior and senior dietetic students who were selected considering their progression through the curriculum. The sample size was determined through total population sampling with the average participation rate of $87.5 \%$ from all participating institutions. The sample was comprised of 516 students from two state universities $\left(\mathrm{n}_{1}=126\right.$ and $\left.\mathrm{n}_{2}=183\right)$ and one private university $(n=207)$. Before signing the written consent form, participants were informed that participation was voluntary; they could skip any questions and drop out of the study at any time; their answers would remain anonymous and would not affect their academic standing.

\section{Instruments}

The questionnaire consisted of eight sections: 1) sociodemographic, 2) interaction with PLHIV, 3) access to information and social media, 4) Asian Value Scales, 5) Beliefs and Value Scales, 6) HIV comprehensive knowledge, 7) HIV and nutrition-specific knowledge, and 8) attitudes. The Asian Value Scale (AVS) and the Beliefs and Values Scales (BVS) had been used in previous studies, while the other questionnaires were developed prior to this study [26]. All questionnaires were translated into the Indonesian Language and tested for readability as well as internal consistency before the data collection began. Questionnaire testing was performed among thirty students from other universities with similar characteristics (age, years of study, and academic background). We used Cronbach's alpha and Kuder Richardson-20 to measure internal consistency (reliability). Table 1 provides information on the questionnaires, constructs, and results of the test.

The previous test on the AVS questionnaire showed that the alpha coefficients for each construct were low; hence, only the total score was suggested for the final analysis [26]. On the other hand, the previous test on the BVS questionnaire demonstrated high internal and test-retest reliability across various religious and nonreligious standpoints [27]. Item responses in the knowledge questionnaire were coded as 'Yes,' 'No' and 'Do Not Know,' with the response of 'Do Not Know' scored as incorrect. Higher scores indicated higher levels of

Table 1 Summary of study instruments

\begin{tabular}{|c|c|c|}
\hline Section & Definition and constructs & Internal consistency \\
\hline Sociodemographic & $\begin{array}{l}\text { Age, gender, years of study, ethnic and family background, religion, and } \\
\text { marital status }\end{array}$ & - \\
\hline Interaction with PLHIV & $\begin{array}{l}\text { Ever known of someone who has HIV, ever participated in HIV courses } \\
\text { or classroom discussion, ever participated in HIV training, and awareness } \\
\text { of HIV-related guidelines or protocols }\end{array}$ & - \\
\hline Access to information and media & $\begin{array}{l}\text { The estimated time spent on media and social media (TV, radio, internet, } \\
\text { newspaper/magazines, Facebook, and Twitter). }\end{array}$ & \\
\hline Asian Value Scales & $\begin{array}{l}\text { Adherence to Asian culture; conformity to norms, family recognition } \\
\text { through achievement, emotional self-control, collectivism, humility, and } \\
\text { filial piety. }\end{array}$ & Cronbach's alpha =0.898 \\
\hline Beliefs and Values Scales & Assessing the level of religiosity and spirituality among study participants & Cronbach's alpha $=0.859$ \\
\hline HIV-comprehensive knowledge & $\begin{array}{l}\text { Basic knowledge of HIV and AIDS; modes of transmission, prevention } \\
\text { method, treatment, and human rights. }\end{array}$ & Kuder-Richardson (KR)-20 $=0.762$ \\
\hline HIV-nutrition specific knowledge & $\begin{array}{l}\text { Nutrition care process (NCP) for HIV patients; nutrition assessment, } \\
\text { diagnosis, intervention, monitoring and evaluation, counseling, as well } \\
\text { as infant and young child feeding practices }\end{array}$ & \\
\hline Attitudes & $\begin{array}{l}\text { Attitudes towards PLHIV measured through agreements with sixteen } \\
\text { statements, which include willingness to treat PLHIV ( } 8 \text { items), personal } \\
\text { responsibility or blame ( } 1 \text { item), perceived dangerousness and fear ( } 4 \text { items), } \\
\text { controllability ( } 1 \text { item), and respect patients' rights ( } 2 \text { items) }\end{array}$ & Cronbach's alpha $=0.763$ \\
\hline
\end{tabular}


HIV knowledge. The correct responses from 35 items were combined to yield a single HIV comprehensive knowledge score. The HIV and nutrition-specific knowledge scores were used as a subscale containing 15 questions and were treated as such in the subsequent statistical analysis. Participants who provided more than $75 \%$ of correct answers were considered to have adequate knowledge.

The attitude questionnaire was developed in accordance with the previous study that tested the attribution of stigma in ten diseases. The study found that stigma towards PLHIV had specific attribution properties, which emphasized the aspects of responsibility, blame, and pity [24]. Our questionnaire consisted of 16 items that were measured using a Likert scale, ranging from 1 (strongly disagree) to 5 (strongly agree); hence, the maximum total score was 80 . The cutoff to determine favorable attitude was 20, in which, the higher score was equal with less favorable or stigmatized attitudes.

\section{Statistical analysis}

The data were analyzed using SPSS 21.0 (SPSS Inc., Chicago, IL, USA, 2012). The mean and standard error of the mean (SE) were used to describe the continuous variables, whereas the proportion was used to describe categorical variables. Differential analysis between the state and private dietetic schools was performed using independent t-test for the continuous variables and Chi-squared test for the categorical variables. No missing values were found in this study. The linear regression test was conducted since the outcome variables were retained in the ratio scale and the stepwise selection method was applied to obtain the best-fit model for the study outcomes. Prior to fitting the regression model, we tested the model assumption to check if the residuals met the criteria, and there seemed to be no clear violation of the model assumptions. The level of statistical significance was determined at $p<0.05$ for all tests.

\section{Results}

\section{Characteristics of study participants}

Of the 516 students participating in this study, $94.0 \%$ were female, $59.9 \%$ studied in a state university, and $74.8 \%$ were Muslim. The mean of participants' age was 20.7 years $(\mathrm{SE} \pm 0.04)$. We found that students from the private university were significantly more varied in terms of their ethnic background, religious practice, and domicile of origin than those from the state universities (Table 2).

Data presented in Table 3 show that most participants had no prior interaction with any PLHIV (77.1\%) and never participated in HIV training (69.8\%). Most of them had participated in HIV discussion or courses (79.7\%), yet, only a few of them were aware of HIV-related

Table 2 Sociodemographic characteristics of the study participants

\begin{tabular}{|c|c|c|c|}
\hline Variables & State University $(N=309)$ & Private University $(N=207)$ & Total $(N=516)$ \\
\hline Age (years, mean $\pm S E$ ) & $20.7 \pm 0.04$ & $20.7 \pm 0.07$ & $20.7 \pm 0.04$ \\
\hline \multicolumn{4}{|l|}{ Gender (n, \%) } \\
\hline Male & $15(4.9)$ & $16(7.7)$ & $31(6.0)$ \\
\hline Female & $294(95.1)$ & $191(92.3)$ & $485(94.0)$ \\
\hline \multicolumn{4}{|l|}{ College year (n, \%) } \\
\hline Junior & $164(53.1)$ & $107(51.7)$ & $271(52.5)$ \\
\hline Senior & $145(46.9)$ & $100(48.3)$ & $245(47.5)$ \\
\hline \multicolumn{4}{|l|}{ Ethnicity $(n, \%) *$} \\
\hline Java & $239(77.3)$ & $81(39.1)$ & $320(62.0)$ \\
\hline Non-Java & $70(22.7)$ & $126(60.9)$ & $196(38.0)$ \\
\hline \multicolumn{4}{|l|}{ Religion $(n, \%)^{*}$} \\
\hline Islam & $257(83.2)$ & $129(62.3)$ & $386(74.8)$ \\
\hline Non-Islam & $52(16.8)$ & $78(37.7)$ & $130(25.2)$ \\
\hline \multicolumn{4}{|l|}{ Marital status (n, \%) } \\
\hline Married & $1(0.3)$ & $2(1.0)$ & $3(0.6)$ \\
\hline Single / not married & $308(99.7)$ & $205(99.0)$ & $513(99.4)$ \\
\hline \multicolumn{4}{|l|}{ Domicile of origin $(n, \%) *$} \\
\hline Urban & $182(58.9)$ & $103(49.7)$ & $285(55.2)$ \\
\hline Sub-urban & $62(20.1)$ & $36(17.4)$ & $98(19.0)$ \\
\hline Rural & 65 (21.0) & 68 (32.9) & $133(25.8)$ \\
\hline
\end{tabular}

$n$ number of participants, $S E$ standard error of the mean

*statistically different at $p<0.05$ (comparisons between university groups with Chi-squared test) 
Table 3 Experience with PLHIV and access to information

\begin{tabular}{|c|c|c|c|}
\hline Variables & State University $(N=309)$ & Private University $(N=207)$ & Total $(N=516)$ \\
\hline \multicolumn{4}{|c|}{ Ever known of PLHIV $(n, \%)$} \\
\hline Yes & $77(24.9)$ & $41(19.8)$ & $118(22.9)$ \\
\hline No & $232(75.1)$ & $166(80.2)$ & $398(77.1)$ \\
\hline \multicolumn{4}{|c|}{ Ever discussed HIV in class $(n, \%) *$} \\
\hline Yes & $223(72.2)$ & $188(90.8)$ & $411(79.7)$ \\
\hline No & $86(27.8)$ & $19(9.2)$ & $105(20.3)$ \\
\hline \multicolumn{4}{|c|}{ Participated in HIV training $(n, \%) *$} \\
\hline Yes & $44(14.2)$ & $112(54.1)$ & $156(30.2)$ \\
\hline No & $265(85.8)$ & $95(45.9)$ & $360(69.8)$ \\
\hline \multicolumn{4}{|c|}{ Aware of HIV protocols $(n, \%) *$} \\
\hline Yes & $83(26.9)$ & $103(49.8)$ & $186(36.0)$ \\
\hline No & $226(73.1)$ & $104(50.2)$ & $330(64.0)$ \\
\hline \multicolumn{4}{|c|}{ Use of TV per day $(n, \%){ }^{*}$} \\
\hline Never & $13(4.2)$ & $13(6.3)$ & $26(5.1)$ \\
\hline$\leq 1 \mathrm{~h}$ & $120(38.8)$ & $51(24.6)$ & $171(33.1)$ \\
\hline $2-3 h$ & $115(37.2)$ & $84(40.6)$ & $199(38.6)$ \\
\hline $4-5 h$ & $37(12.0)$ & $29(14.0)$ & $66(12.8)$ \\
\hline $6-7 \mathrm{~h}$ & $18(5.8)$ & $11(5.3)$ & $29(5.6)$ \\
\hline$>7 h$ & $6(2.0)$ & $19(9.2)$ & $25(4.8)$ \\
\hline \multicolumn{4}{|c|}{ Use of radio per day $(n, \%) *$} \\
\hline Never & $96(31.1)$ & $99(47.8)$ & $195(37.8)$ \\
\hline$\leq 1 \mathrm{~h}$ & $157(50.8)$ & $81(39.1)$ & $238(46.1)$ \\
\hline $2-3 h$ & $44(14.2)$ & $14(6.8)$ & $58(11.2)$ \\
\hline $4-5 h$ & $9(2.9)$ & $7(3.4)$ & $16(3.1)$ \\
\hline $6-7 \mathrm{~h}$ & $2(0.7)$ & $2(1.0)$ & $4(0.8)$ \\
\hline$>7 \mathrm{~h}$ & $1(0.3)$ & $4(1.9)$ & $5(1.0)$ \\
\hline \multicolumn{4}{|c|}{ Use of internet per day $(n, \%) *$} \\
\hline$\leq 1 \mathrm{~h}$ & $5(1.6)$ & $17(8.2)$ & $22(4.3)$ \\
\hline $2-3 h$ & $36(11.7)$ & 55 (26.6) & $91(17.6)$ \\
\hline $4-5 h$ & $91(29.4)$ & $46(22.2)$ & $137(26.6)$ \\
\hline $6-7 \mathrm{~h}$ & $63(20.4)$ & $31(15.0)$ & $94(18.2)$ \\
\hline$>7 \mathrm{~h}$ & $114(36.9)$ & $58(28.0)$ & $172(33.3)$ \\
\hline \multicolumn{4}{|c|}{ Use of printed media per day $(n, \%)$} \\
\hline Never & $84(27.2)$ & $66(31.9)$ & $150(29.1)$ \\
\hline$\leq 1 \mathrm{~h}$ & $191(61.9)$ & $112(54.1)$ & $303(58.7)$ \\
\hline $2-3 h$ & $30(9.7)$ & $23(11.1)$ & $53(10.3)$ \\
\hline $4-5 \mathrm{~h}$ & $2(0.6)$ & $0(0.0)$ & $2(0.4)$ \\
\hline $6-7 h$ & $2(0.6)$ & $5(2.4)$ & $7(1.3)$ \\
\hline$>7 \mathrm{~h}$ & $0(0.0)$ & $1(0.5)$ & $1(0.2)$ \\
\hline \multicolumn{4}{|c|}{ Access to Facebook per day $(n, \%)^{*}$} \\
\hline Never & $47(15.2)$ & $25(12.1)$ & $72(14.0)$ \\
\hline$\leq 1 \mathrm{~h}$ & $206(66.7)$ & $81(39.1)$ & $287(55.6)$ \\
\hline $2-3 h$ & $37(12.0)$ & $60(29.0)$ & $97(18.8)$ \\
\hline $4-5 h$ & $13(4.2)$ & $20(9.7)$ & $33(6.4)$ \\
\hline
\end{tabular}


Table 3 Experience with PLHIV and access to information (Continued)

\begin{tabular}{clll}
\hline Variables & State University $(N=309)$ & Private University $(N=207)$ & Total $(N=516)$ \\
\hline $6-7 \mathrm{~h}$ & $5(1.6)$ & $12(5.8)$ & $17(3.3)$ \\
$>7 \mathrm{~h}$ & $1(0.3)$ & $9(4.3)$ & $10(1.9)$ \\
Access to Twitter per day $(\mathrm{n}, \%) *$ & & $227(44.0)$ \\
Never & $118(38.2)$ & $109(52.6)$ & $221(42.8)$ \\
$\leq 1 \mathrm{~h}$ & $150(48.5)$ & $71(34.3)$ & $45(8.7)$ \\
$2-3 \mathrm{~h}$ & $25(8.1)$ & $20(9.7)$ & $14(2.7)$ \\
$4-5 \mathrm{~h}$ & $10(3.2)$ & $4(1.9)$ & $5(1.0)$ \\
$6-7 \mathrm{~h}$ & $4(1.3)$ & $1(0.5)$ & $4(0.8)$ \\
$>7 \mathrm{~h}$ & $2(0.7)$ & $2(1.0)$ & \\
\hline
\end{tabular}

$n$ number of participants

*statistically different at $p<0.05$ (comparisons between university groups with Chi-squared test)

guidelines and protocols (36.0\%). Students from the private university were found to have higher opportunities to take part in HIV discourse and undergo training. Likewise, they were more aware of the HIV-related guidelines and protocols $(p<0.05)$. We also found that most participants obtained information from the television (94.9\%) and Internet (95.7\%), and spent a significant amount of time accessing social media.

\section{Cultural values and spirituality}

The mean AVS score of the participants was 4.9 (SE \pm 0.02 ) out of 7.0 considered as high adherence to the Asian values [28]. The AVS subscales were calculated to provide a clear depiction of the tenets of the Asian philosophy; however, these subscales were excluded from further analysis considering the low alpha coefficient [26]. Similarly, with an average score of $58.2(\mathrm{SE} \pm 0.36)$ on the BVS test, the participants showed a high level of spirituality (97.3\%) [27]. There were no significant differences in the BVS and AVS scores between students from the public and private dietetic schools (Table 4).

\section{HIV knowledge and attitudes}

The mean and SE for the HIV comprehensive and nutrition-specific knowledge were $19.9 \pm 0.19$ and $8.0 \pm$ 0.11 , respectively. With the cutoff of $75 \%$ for all composite scores, we found that less than $3 \%$ of the participants had adequate knowledge of the standardized nutrition care for HIV patients. Similarly, the mean and SE of the attitudes score was $42.7 \pm 0.27$, which showed that only $0.4 \%$ of the respondents had positive attitudes towards PLHIV. We found no significant differences in scores of knowledge and attitudes between students from private and state dietetics schools as presented in Table 5 .

\section{Factors associated with HIV knowledge and stigma}

Using the attribution theory, we studied the factors associated with HIV knowledge and attitudes. The factors being tested were sociodemographic characteristics,

Table 4 Social, cultural, and spiritual characteristics of the study participants

\begin{tabular}{llll}
\hline Variables & State University $(N=309)$ & Private University $(N=207)$ & Total $(N=516)$ \\
\hline Asian Values Scales (AVS) & & & \\
Total scales (mean \pm SE) & $4.9 \pm 0.03$ & $4.8 \pm 0.04$ & $4.9 \pm 0.02$ \\
Conformity to norms & $4.7 \pm 0.03$ & $4.7 \pm 0.04$ & $4.7 \pm 0.02$ \\
Family recognition & $4.6 \pm 0.06$ & $4.8 \pm 0.09$ & $4.7 \pm 0.05$ \\
Emotional self-control * & $5.1 \pm 0.04$ & $4.9 \pm 0.06$ & $5.0 \pm 0.03$ \\
Collectivism * & $5.2 \pm 0.04$ & $4.9 \pm 0.08$ & $5.0 \pm 0.04$ \\
Humility * & $5.4 \pm 0.05$ & $5.2 \pm 0.07$ & $5.3 \pm 0.04$ \\
Filial piety * & $4.6 \pm 0.04$ & $4.7 \pm 0.05$ & $4.6 \pm 0.03$ \\
Beliefs and Values Scales (BVS) & & & $57.5 \pm 0.65$ \\
Total scales (mean \pm SE) & $58.7 \pm 0.42$ & $9(4.3)$ & $58.2 \pm 0.36$ \\
Low (n, \%) & $5(1.6)$ & $198(95.7)$ & $14(2.7)$ \\
High (n, \%) & $304(98.4)$ & $502(97.3)$ \\
\hline
\end{tabular}

$n$ number of participants, $S E$ standard error of the mean

*statistically different at $p<0.05$ (comparisons between university groups with t-test) 
Table 5 HIV knowledge and attitudes among study participants

\begin{tabular}{llll}
\hline Variables & State University $(N=309)$ & Private University $(N=207)$ & Total $(N=516)$ \\
\hline HIV comprehensive knowledge (mean \pm SE) & $21.3 \pm 0.21$ & $18.1 \pm 0.33$ & $19.9 \pm 0.19$ \\
Low $(n, \%)$ & $299(96.8)$ & $204(98.6)$ & $503(97.5)$ \\
High $(n, \%)$ & $10(3.2)$ & $3(1.4)$ & $13(2.5)$ \\
HIV-nutrition knowledge (mean \pm SE) & $8.5 \pm 0.13$ & $7.3 \pm 0.18$ & $8.0 \pm 0.11$ \\
Low $(n, \%)$ & $302(97.7)$ & $202(97.6)$ & $504(97.7)$ \\
High $(n, \%)$ & $7(2.3)$ & $5(2.4)$ & $12(2.3)$ \\
HIV stigma (mean $\pm S E)$ & $41.2 \pm 0.32$ & $44.9 \pm 0.43$ & $42.7 \pm 0.27$ \\
Not favorable $(n, \%)$ & $309(100.0)$ & $205(99.0)$ & $514(99.6)$ \\
Favorable $(n, \%)$ & $0(0.0)$ & $2(1.0)$ & $2(0.4)$ \\
\hline
\end{tabular}

$n$ number of participants, $S E$ standard error of the mean

*statistically different at $p<0.05$ (comparisons between university groups with t-test)

interaction with key populations, participation in training, exposure to HIV discourse in the classroom setting, access to information, adherence to Asian values, and spirituality. The variable of HIV comprehensive knowledge was included in the linear regression test for the outcome variable of attitudes.

Table 6 presents the selected regression model for HIV knowledge and attitude; sub-analyses were

Table 6 Results of linear regression analysis of knowledge and attitude towards PLHIV

\begin{tabular}{lcllll}
\hline & $B$ & SE & $\beta$ & $t$ & $p$ \\
\hline Outcome variable: HIV comprehensive knowledge & & \\
Constant & 15.360 & 1.329 & 11.560 & $<.001$ \\
Type of university & -3.186 & .369 & -.353 & -8.641 & $<.001$ \\
Beliefs and values scale & .117 & .021 & .218 & 5.483 & $<.001$ \\
Interaction with PLHIV & -.962 & .435 & -.091 & -2.211 & .028 \\
Access to printed media & .514 & .238 & .086 & 2.156 & .032 \\
Years of study & -.776 & .362 & -.088 & -2.145 & .032 \\
Ever discussed HIV in class & -.905 & .451 & -.082 & -2.004 & .046 \\
Adjusted R ${ }^{2}=0.199, F=22.294$, & $p<.001$ & & & & \\
Outcome variable: HIV-nutrition knowledge & & & \\
Constant & 6.218 & .757 & & 8.210 & $<.001$ \\
Type of university & -1.277 & .217 & -.253 & -5.870 & $<.001$ \\
Beliefs and values scale & .047 & .013 & .155 & 3.692 & $<.001$ \\
Ever discussed HIV in class & -.884 & .265 & -.144 & -3.340 & .001 \\
Years of study & -.444 & .208 & -.090 & -2.131 & .034 \\
Adjusted R ${ }^{2}=0.098, F=15.023, p<0.001$ & & & & \\
Outcome variable: HIV-related stigma & & & & \\
Constant & 49.645 & 1.336 & & 37.173 & $<.001$ \\
HIV comprehensive knowledge & -.361 & .059 & -.264 & -6.085 & $<.001$ \\
Type of university & 2.723 & .593 & .220 & 4.595 & $<.001$ \\
Ever discussed HIV in class & -1.782 & .629 & -.118 & -2.835 & .005 \\
Ethnicity & -1.201 & .547 & -.096 & -2.196 & .029 \\
Adjusted $R^{2}=0.163, F=26.021, p<0.001$ & & & & \\
\hline
\end{tabular}

performed to create a model to explain the nutritionspecific knowledge variable. Six predictor variables were retained in the HIV comprehensive knowledge model: types of university affiliation, beliefs and values, interaction with PLHIV, access to printed media, years of study, and participation in HIV discussion (adjusted $\left.\mathrm{R}^{2}=0.199, \mathrm{~F}=22.294, p<0.001\right)$. For the subset analysis, the model contained university affiliation, spirituality, discussion participation and years of study as predictor variables (adjusted $\mathrm{R}^{2}=0.098, \mathrm{~F}=15.023, p<0.001$ ). Moreover, HIV comprehensive knowledge, university affiliation, participation in HIV discourse and ethnicity were found to correlate with attitudes (adjusted $\mathrm{R}^{2}=$ 0.163, $\mathrm{F}=26.021, p<0.001$ ).

\section{Discussion}

According to the attribution theory, the problems of HIV stigma and discrimination can stem from both internal and external factors [23]. Our study supports this theory as we found that HIV knowledge and attitudes were determined by several external factors such as academic experience, interaction with key populations, and access to media; and these were on top of the internal factors such as beliefs and cultural background. This study is the first to report on HIV knowledge and attitudes among dietetic students in Indonesia. Our findings show that the level of HIV comprehension was low and stigmatized attitudes were high, which have been observed elsewhere among other health care students [1719, 29].

Dietitians and dietetic students are often overlooked in the discussion about HIV despite their critical roles in HIV care and control. Training is mostly provided to doctors and nurses who are considered to have higher responsibilities in treatment and at the same time more vulnerable due to their frequent contact with the patients [30]. Even when it is provided, topics delivered during the training were also limited to the technical or clinical necessities and often missed the more 
fundamental aspect of building a good relationship between patients and providers [31]. The Indonesian National AIDS Commission highlighted the need to equip HIV training for health professionals with the principles of effective service delivery, anti-discriminatory behavior, and human rights [32].

Similar to the medical schools, all dietetic schools in Indonesia follow the national curriculum guideline [33]. The Indonesian Nutrition Science Collegium and The Indonesian Association of Nutrition Academic Institution developed a dietetic curriculum in Indonesia. The curriculum is designed according to an established set of standard professional competencies and should be followed by all dietetic schools in Indonesia. However, each university can develop electives and courses that reflect their academic mission, yet courses in HIV and AIDS are not mandatory. This gap explains our findings that although most participants have enrolled in a class that discussed HIV, their understanding of the topic remains low. When HIV becomes an optional topic in the curriculum, there is no guarantee that students would receive adequate information about HIV which neither builds the level of professional competency needed to treat the patients nor cultivates non-prejudice attitudes.

Of special concern, the regression analysis consistently presented that university affiliation was related to knowledge and attitude towards PLHIV. Comparative analysis also revealed that students from the private university scored lower than those from the state university in all types of tests. The apparent difference in the way dietetic schools teach HIV to their students triggers discussion of what is being taught in each institution and requires further investigation considering the scarcity in the literature on nutrition education in Indonesia. Some assumptions might be taken from the medical education system. Private medical schools are known to have less bureaucratic burdens and more liberty to adopt innovations in exchange for reduced governmental subsidies. However, the lack of government control is likely to hamper the quality of education as it has been reported that the newer and smaller private institutions are having trouble in establishing an appropriate quality assurance system and accreditation [33-36].

Enforcing all dietetic schools to follow the same set of regulations for curriculum implementation and quality assurance might be necessary to ensure students having similar academic experiences and developing the skills needed in the workforce. Educational innovation and experimentation must be reported and documented properly, thus, allowing replication and comparative analysis [34]. Our study suggests that to improve HIV knowledge and attitude, dietetic schools need to ensure that students have opportunities to interact with the patients or key populations, have access to accurate information sources and discuss HIV in a class setting with their peers and instructors. These findings correspond with previous studies, which indicated higher exposure to HIV information and key populations might improve awareness and acceptance of the individuals [12, 29, 37].

Creating a safe, secure, and supportive learning environment is important to encourage an open and honest discussion about HIV. As suggested in our study, in a conservative country like Indonesia where HIV discussion tends to attract controversy, understanding the interlinking of religion, culture, sexuality, and HIV is important. A study in Bangladesh proposed the need to provide training to the teachers in addition to efforts in improving the curriculum. Through training, teachers can develop confidence and skills in imparting HIV knowledge with greater sensitivity, and thus inspire more positive attitudes among students [38, 39].

We defined stigma in this study as any type of negative attitude and misconduct performed by health professionals towards PLHIV due to their HIV status. However, stigma is a multifaceted problem, not one rooted in a simple causality. The attribution theory lends credence to the explanation that the process of attributing stigma usually happens without the person's awareness [40]. Considering the tenets of the attribution theory that underpin the attributes given to PLHIV: personal responsibility, controllability, perceived dangerousness, and familiarity, an effort beyond an instructional approach is much-needed. Additionally, behavioral studies found that HIV-related stigma is particularly fluid compared to other diseases. The perceived dangerousness, for example, is amenable to following swift advancement in treatment and control [24]. Therefore, several studies suggested the need to conduct multilayered intervention targeting factors at the individual, interpersonal, community, institution, and structural levels to reduce stigma $[41,42]$.

Finally, addressing the stigma towards PLHIV among health professionals is important to prevent further public health consequences. Stigma in health facilities disrupts patients-providers communication that might lead to distrust and poor adherence to medication. It might also deter patients from accessing proper care in a timely manner, counseling and testing services as well as other harm reduction interventions [13, 21, 43-45]. Reducing stigma matters because it also has the potential to open further academic discussion and debate.

\section{Limitations}

Several limitations should be taken into consideration in interpreting the results of this study. Firstly, the sample of dietetic students was selected conveniently from three universities only. Although these universities had wide coverage of student intake throughout Indonesia, which 
enables a culturally diverse study sample and might be typical of dietetic students in Indonesia, this assumption was not validated in the analysis. Nonetheless, the limited study setting might affect the external validity of the study and inferences must be made with caution to the study setting.

Secondly, the survey instruments might influence responses from the participants due to the use of standard Indonesian language and dialect, which may not address the discrepancies in language comprehension from participants who come from remote areas of Indonesia. As disparity in the quality of education is evident throughout Indonesia, students coming from marginalized areas might have trouble understanding the few jargons used in the questionnaire, despite our effort to use plain language. All this might explain the result of the reliability test of the instruments. Thirdly, considering the sensitivity of the issues, there is a risk of social desirability bias in the responses causing stigma to be underreported. However, the use of a self-administered questionnaire that gives more freedom and privacy to participants might minimize the problem. Finally, considering the nature of the cross-sectional study, our findings can only suggest an association with HIV knowledge and stigma.

\section{Conclusions}

HIV-related knowledge among Indonesian dietetic students is low while the prejudicial attitudes are inappropriately high. Findings in our study also correspond with the attribution theory and provide evidence to our hypotheses that environmental factors determined HIV knowledge and attitudes as much as personal values. The differential findings between universities and lack of positive result in the cognition area despite the participation in HIV discourse, underline the need for further analysis on the education system and curriculum of dietetic schools. Evaluation of the teaching conduct might be necessary to reveal the learning process in each institution that may or may not dispel stigma among the students.

The findings of this study recommend two opportunities for intervention. First, given students are generally lacking in proper and formal training about HIV, curriculum improvement needs to be conducted systematically. This could be done by either strengthening the current curriculum with HIV discussion in all relevant courses or developing electives or mandatory courses on HIV and nutrition. Whichever options are deemed more viable, they should ensure enough room to discuss HIV beyond the clinical aspects. Since personal beliefs heavily influence HIV knowledge and attitudes, students need to be equipped with the opportunity to analyze and discuss their beliefs and values of HIV so that any potential prejudice can be mitigated. Second, considering high access to media and its influence on HIV awareness, social campaign activities are necessary to foster positive attitudes and acceptance of PLHIV, which calls for a multilayered approach. This type of intervention requires partnerships with cultural and religious experts.

\section{Abbreviations \\ HIV: Human Immunodeficiency Virus; AIDS: Acquired Immune Deficiency Syndrome; PLHIV: People Living With HIV; SD: Standard deviation; \\ SE: Standard error of the mean; AVS: Asian Values Scales; BVS: Beliefs and Values Scales}

\section{Acknowledgments}

We would like to acknowledge and thank all the study participants and enumerators. We also thank all academic office staff from the three dietetic schools in Indonesia for assisting the study team to connect with the study participants.

\section{Authors' contributions}

MTPLK was responsible for the design, data collection and acquisition, analysis and interpretation, and drafting of the manuscript. TK, NM, SBP, LKY, and WWH participated in the study design and provided supervision and assistance towards data analysis, interpretation, and critically revising the manuscript. All authors read and approved the final manuscript.

\section{Funding}

Financial support for this study was obtained from the 2017 Arts, Humanities \& Social Sciences Small Grant Program from Kansas State University. The first author received the Fulbright Ph.D. Scholarship to support her doctoral study. This study has not received any financial support for publication charges.

\section{Availability of data and materials}

All data generated or analyzed during this study are included in this published article.

\section{Ethics approval and consent to participate}

The study received ethical approval from the Kansas State University Institutional Board Review (IRB) \# 8555 and the Medical and Health Research Ethics Committee (MHREC) Faculty of Medicine Universitas Gadjah Mada -

Dr. Sardjito General Hospital, reference number KE/FK/0129/EC/2017. Written informed consent was obtained from all study participants prior to the inclusion in the study and there was no coercion from the academic authorities in the dietetic schools for students to participate in the study. Before consenting to the study, students were informed that participation was voluntary; they could skip any questions and drop out of the study at any time; their answer would remain anonymous and would not affect their academic standing. Consent to publish was not sought as it was inapplicable, considering no individual participant's data were reported in the article in any form such as images, videos, or voice recording.

\section{Consent for publication}

Not applicable.

\section{Competing interests}

The authors declare that they have no competing interests.

\section{Author details}

${ }^{1}$ Department of Nutrition and Health, Faculty of Medicine, Public Health, and Nursing, Universitas Gadjah Mada, Yogyakarta, Indonesia. ${ }^{2}$ Department of Food, Nutrition, Dietetics, and Health, College of Health and Human Sciences, Kansas State University, Manhattan, Kansas, USA. ${ }^{3}$ A.Q. Miller School of Journalism and Mass Communications, College of Arts and Sciences, Kansas State University, Manhattan, Kansas, USA. ${ }^{4}$ Department of Statistics, 
College of Arts and Sciences, Kansas State University, Manhattan, Kansas, USA.

\section{Received: 2 December 2019 Accepted: 28 August 2020} Published online: 09 September 2020

\section{References}

1. UNAIDS. UNAIDS data 2018; 2018. https://www.unaids.org/en/resources/ documents/2018/unaids-data-2018. Accessed 26 March 2020.

2. de Pee S, Semba RD. Role of nutrition in HIV infection: review of evidence for more effective programming in resource-limited settings. Food Nutr Bull. 2010;31(4):S313-44.

3. Poda GG, Hsu CY, Chao JC. Malnutrition is associated with HIV infection in children less than 5 years in Bobo-Dioulasso City, Burkina Faso: a casecontrol study. Medicine (Baltimore). 2017;96(21):e7019. https://doi.org/10. 1097/MD.0000000000007019.

4. Negessie A, Jara D, Taddele M, Burrowes S. Determinants of undernutrition among adult patients receiving antiretroviral therapy at Debre Markos referral hospital, Northwest Ethiopia: a case-control study design. BMC Nutr. 2019:5:20. https://doi.org/10.1186/s40795-019-0284-9.

5. Apornpong T, Han WM, Chattranukulchai P, Siwamogsatham S, Wattanachanya L, Gatechompol S, et al. Higher proportion of abnormal nutritional status among well suppressed HIV-infected elderly Asians compared to HIV-negative individuals. AIDS Res Hum Retrovir. 2020;36(7): 590-6. https://doi.org/10.1089/AID.2019.0285.

6. Thimmapuram R, Lanka S, Esswein A, Dall L. Correlation of nutrition with immune status in human immunodeficiency virus outpatients. Mo Med. 2019;116(4):336-9.

7. Shin SS, Satyanarayana VA, Ekstrand ML, Carpenter CL, Wang Q, Yadav K, et al. The effect of community-based nutritional interventions on children of women living with HIV in rural India: a 2 × 2 factorial intervention trial. Clin Infect Dis. 2019. https://doi.org/10.1093/cid/ciz1009.

8. Dong KR, Imai CM. Medical nutrition therapy for HIV and AIDS. In: Mahan LK, Escott-Stump S, Raymond JL, editors. Krause's food and the nutrition care process. St. Louis: Elsevier; 2012.

9. Fields-Gardner C, Campa A. Position of the American dietetic association: nutrition intervention and human immunodeficiency virus infection. J Am Diet Assoc. 2010;110(7):1105-19. https://doi.org/10.1016/j.jada.2010.05.020.

10. Pribram V. Nutrition and HIV. Hoboken: Wiley-Blackwell; 2010.

11. Paxton S, Gonzales G, Uppakaew K, Abraham KK, Okta S, Green C, et al. AIDS-related discrimination in Asia. AIDS Care. 2005;17(4):413-24. https://doi. org/10.1080/09540120412331299807.

12. Waluyo A, Culbert GJ, Levy J, Norr KF. Understanding HIV-related stigma among Indonesian nurses. J Assoc Nurses AIDS Care. 2015;26(1):69-80. https://doi.org/10.1016/j.jana.2014.03.001.

13. Merati T, Supriyadi YF. The disjunction between policy and practice: HIV discrimination in health care and employment in Indonesia. AIDS Care. 2005:17(Suppl 2):S175-9. https://doi.org/10.1080/09540120500119932.

14. Gagnon M. Re-thinking HIV-related stigma in health care settings: a qualitative study. J Assoc Nurses AIDS Care. 2015;26(6):703-19. https://doi. org/10.1016/j.jana.2015.07.005.

15. Palar K, Derose KP, Linnemayr S, Smith A, Farias H, Wagner G, et al. Impact of food support on food security and body weight among HIV antiretroviral therapy recipients in Honduras: a pilot intervention trial. AIDS Care. 2015; 27(4):409-15. https://doi.org/10.1080/09540121.2014.983041.

16. Lui P, Sarangapany J, Begley K, Coote K, Kishore K. Medical and nursing students perceived knowledge, attitudes, and practices concerning human immunodeficiency virus. ISRN Public Health. 2014;2014:1-9. https://doi.org/ 10.1155/2014/975875.

17. Premadasa G, Sadek M, Ellepola A, Sreedharan J, Muttappallymyalil J. Knowledge of and attitudes towards HIV/AIDS: a survey among dental students in Ajman, UAE. J Investig Clin Dent. 2015;6(2):147-55. https://doi.org/10.1111/jicd.12080.

18. Baytner-Zamir R, Lorber M, Hermoni D. Assessment of the knowledge and attitudes regarding HIV/AIDS among pre-clinical medical students in Israel. BMC Res Notes. 2014;7:168. https://doi.org/10.1186/1756-0500-7-168

19. Akin S, Mendi B, Mendi O, Durna Z. Turkish nursing students' knowledge of and attitudes towards patients with HIV/AIDS. J Clin Nurs. 2013;22(23-24): 3361-71. https://doi.org/10.1111/jocn.12378.

20. Liem A, Adiyanti MG. Bidan cantik: psychoeducation on HIV and AIDS to improve the service quality of midwives at Yogyakarta public health center. HIV AIDS Rev. 2013;12(1):14-22. https://doi.org/10.1016/j.hivar.2013.02.001.
21. Wisaksana R, Alisjahbana B, van Crevel R, Kesumah N, Sudjana P, Sumantri R. Challenges in delivering HIV-care in Indonesia: experience from a referral hospital. Acta Med Indones. 2009;41(Suppl 1):45-51.

22. Ion A, Elston D. Examining the health care experiences of women living with human immunodeficiency virus (HIV) and perceived HIV-related stigma. Womens Health Issues. 2015;25(4):410-9. https://doi.org/10.1016/j. whi.2015.03.012

23. Forsterling F. Attribution: an introduction to theories, research, and applications. Philadelphia: Psychology Press, Ltd.; 2001.

24. Weiner B, Perry RP, Magnusson J. An attributional analysis of reactions to stigmas. J Pers Soc Psychol. 1988;55(5):738-48. https://doi.org/10.1037// 0022-3514.55.5.738.

25. Center for Data and Information Indonesian Ministry of Health. The general situation of HIV and AIDS and HIV testing; 2017. https://pusdatin.kemkes.go. id/article/view/19042200004/situasi-umum-hiv-aids-dan-tes-hiv.html. Accessed 26 March 2020

26. Kim BSK, Atkinson DR, Yang PH. The Asian value scale: development, factor analysis, validation, and reliability. J Couns Psychol. 1999;46(3):342-52. https://doi.org/10.1037/0022-0167.46.3.342.

27. King M, Jones L, Barnes K, Low J, Walker C, Wilkinson S, et al. Measuring spiritual belief: development and standardization of a beliefs and values scale. Psychol Med. 2006;36(3):417-25. https://doi.org/10.1017/ S003329170500629X.

28. Kim BSK, Atkinson DR. Asian American client adherence to Asian cultura values, counselor expression of cultural values, counselor ethnicity, and career counseling process. J Couns Psychol. 2002;49(1):3-13. https://doi.org/ 10.1037//0022-0167.49.1.3.

29. Jin H, Earnshaw VA, Wickersham JA, Kamarulzaman A, Desai MM, John J, et al. An assessment of healthcare students' attitudes toward patients with or at high risk for HIV: implications for education and cultural competency. AIDS Care. 2014;26(10):1223-8. https://doi.org/10.1080/09540121.2014. 894616.

30. Mbanya D, Ateudjieu J, Tagny CT, Moudourou S, Lobe MM, Kaptue L. Risk factors for transmission of HIV in a hospital environment of Yaounde, Cameroon. Int J Environ Res Public Health. 2010;7(5):2085-100. https://doi. org/10.3390/ijerph7052085.

31. Kusuma MTPL, Kidd T, Muturi N, Procter SB, Yarrow L, Hsu WW. The symbolic meaning of HIV: understanding lecturers' ambivalence over teaching HIV to dietetic students. J Int Assoc Provid AIDS Care. 2020;19: 2325958220939755. https://doi.org/10.1177/2325958220939755.

32. Indonesian National AIDS Commission. Global AIDS response progress reporting, Indonesia country progress report 2014: reporting period 2012 2013; 2014. https://www.unaids.org/sites/default/files/country/documents/ IDN_narrative_report_2014.pdf. Accessed 5 April 2017.

33. Amin Z, Hoon Eng K, Gwee M, Dow Rhoon K, Chay HT. Medical education in Southeast Asia: emerging issues, challenges, and opportunities. Med Educ. 2005;39(8):829-32. https://doi.org/10.1111/j.1365-2929.2005.02229.x.

34. Amin Z. Medical education in Asia: is it a time for optimism? Ann Acad Med Singap. 2004;33(2):264-6.

35. Susanti D. Privatisation and marketisation of higher education in Indonesia: the challenge for equal access and academic values. High Educ. 2011;61(2): 209-18. https://doi.org/10.1007/s10734-010-9333-7.

36. Asian Development Bank. Private higher education across Asia: expanding access, searching for quality. Mandaluyong City: Asian Development Bank; 2012.

37. Vorasane S, Jimba M, Kikuchi K, Yasuoka J, Nanishi K, Durham J, et al. An investigation of stigmatizing attitudes towards people living with HIV/AIDS by doctors and nurses in Vientiane, Lao PDR. BMC Health Serv Res. 2017; 17(1):125. https://doi.org/10.1186/s12913-017-2068-8.

38. Sarma H, Islam MA, Khan JR, Chowdhury KIA, Gazi R. Impact of teachers training on HIV/AIDS education program among secondary school students in Bangladesh: a cross-sectional survey. PLoS One. 2017;12(7):e0181627. https://doi.org/10.1371/journal.pone.0181627.

39. Sarma H, Oliveras E. Implementing HIV/AIDS education: impact of teachers' training on HIV/AIDS education in Bangladesh. J Health Popul Nutr. 2013; 31(1):20-7. https://doi.org/10.3329/jhpn.v31i1.14745.

40. Harvey $\mathrm{JH}$, Weary G. Current issues in attribution theory and research. Annu Rev Psychol. 1984;35:427-59. https://doi.org/10.1146/annurev.ps.35.020184 002235 .

41. Feyissa GT, Lockwood C, Woldie M, Munn Z. Reducing HIV-related stigma and discrimination in healthcare settings: a systematic review of 
quantitative evidence. PLoS One. 2019;14(1):e0211298. https://doi.org/10. 1371/journal.pone.0211298.

42. Rao D, Elshafei A, Nguyen M, Hatzenbuehler ML, Frey S, Go VF. A systematic review of multi-level stigma interventions: state of the science and future directions. BMC Med. 2019;17(1):41. https://doi.org/ 10.1186/s12916-018-1244-y.

43. Chan KY, Stoové MA, Reidpath DD. Stigma, social reciprocity, and exclusion of HIV/AIDS patients with illicit drug histories: a study of Thai nurses' attitudes. Harm Reduct J. 2008;5(1):28. https://doi.org/10.1186/1477-7517-528.

44. Nyblade L, Stockton MA, Giger K, Bond V, Ekstrand ML, Lean RM, et al. Stigma in health facilities: why it matters and how we can change it. BMC Med. 2019;17(1):25. https://doi.org/10.1186/s12916-019-1256-2.

45. Varas-Diaz N, Neilands TB, Malave Rivera S, Betancourt E. Religion and HIV/ AIDS stigma: implications for health professionals in Puerto Rico. Glob Public Health. 2010;5(3):295-312. https://doi.org/10.1080/ 17441690903436581 .

\section{Publisher's Note}

Springer Nature remains neutral with regard to jurisdictional claims in published maps and institutional affiliations.

Ready to submit your research? Choose BMC and benefit from:

- fast, convenient online submission

- thorough peer review by experienced researchers in your field

- rapid publication on acceptance

- support for research data, including large and complex data types

- gold Open Access which fosters wider collaboration and increased citations

- maximum visibility for your research: over $100 \mathrm{M}$ website views per year

At BMC, research is always in progress.

Learn more biomedcentral.com/submissions 